\title{
Influence of Altitude on Biochemical Properties of European Beech (Fagus sylvatica L.) Forest Soils
}

\author{
Mauro De Feudis ${ }^{1}$, Valeria Cardelli ${ }^{2}$, Luisa Massaccesi ${ }^{1}$, Alessandra Lagomarsino ${ }^{3}$, \\ Flavio Fornasier ${ }^{4}$, Danielle Janaina Westphalen ${ }^{2}$, Stefania Cocco ${ }^{2}$, Giuseppe Corti ${ }^{2}$ \\ and Alberto Agnelli 1,5,* \\ 1 Department of Agricultural, Food and Environmental Science, University of Perugia, 06121 Perugia, Italy; \\ mauro.defeudis@studenti.unipg.it (M.D.F.); luisa.massaccesi@unipg.it (L.M.) \\ 2 Department of Agricultural, Food and Environmental Science, Polytechnic University of Marche, \\ 60131 Ancona, Italy; v.cardelli@staff.univpm.it (V.C.); daniellejanaina76@gmail.com (D.J.W.); \\ s.cocco@univpm.it (S.C.); g.corti@univpm.it (G.C.) \\ 3 Council for Agricultural Research and Agricultural Economy Analysis, Research Centre for Agrobiology \\ and Pedology, 50125 Firenze, Italy; alessandra.lagomarsino@crea.gov.it \\ 4 Council for Agricultural Research and Agricultural Economy Analysis, Research Centre for Soil-Plant \\ System Studies, 34170 Gorizia, Italy; flavio.fornasier@crea.gov.it \\ 5 Institute for Ecosystem Study, National Research Council, 50019 Sesto Fiorentino (Firenze), Italy \\ * Correspondence: alberto.agnelli@unipg.it; Tel.: +39-075-5856451
}

Academic Editor: Timothy A. Martin

Received: 5 May 2017; Accepted: 13 June 2017; Published: 17 June 2017

\begin{abstract}
Climate warming is predicted to raise the mean global temperature by $1{ }^{\circ} \mathrm{C}$ in the next 50 years, and this change is believed to be capable of affecting soil organic matter cycling and nutrient availability. With the aim of increasing knowledge on the response of forest soils to the ongoing climate change, we used altitude as a proxy for temperature change and studied chemical and biochemical properties of European beech (Fagus sylvatica L.) forest soils at two altitudes (800 and $1000 \mathrm{~m}$ ) from central Apennines (Italy). Results showed that $1^{\circ} \mathrm{C}$ of mean annual air temperature difference between the sites at the two altitudes had greater effect on the mineral horizons than on the organic horizons. At higher altitude, mineral soil had limited development, higher $\mathrm{pH}$, and higher organic matter content due to the lower efficiency of the microbial community. Enzymatic activities of the organic horizons were generally not affected by altitude. Conversely, we observed a higher activity of xylosidase, $\beta$-glucosidase, alkaline phosphomonoesterase, arylsulfatase, and leucine-aminopeptidase in the sub-superficial horizons (Bw1 and Bw2) of the soils at $1000 \mathrm{~m}$. We hypothesized that, as a response to environmental and climatic constraints occurring at higher altitude, plant roots increase the production of enzymes directly and/or indirectly by triggering the microbial community through exudation.
\end{abstract}

Keywords: organic horizons; soil organic matter; soil microbial biomass carbon; soil enzymatic activity; climate change

\section{Introduction}

The global mean surface temperature increased by $0.65-1.06{ }^{\circ} \mathrm{C}$ from 1880 to 2012 , and a further increase of $1^{\circ} \mathrm{C}$ is expected in the next fifty years [1]. The European region with a Mediterranean type of climate is the transition zone between the arid region of north Africa and the temperate and rainy region of central Europe, and could be one of the most affected by climate change [2,3]. Forest ecosystems, besides providing important ecological services [4], store a large amount of organic $\mathrm{C}$ in the soil [5], thus contrasting the atmospheric $\mathrm{CO}_{2}$ increase. As forests cover $20-30 \%$ of the 
total Mediterranean land area [6], it is useful to understand the possible impact of the ongoing global warming on the content and dynamic of the soil organic matter (SOM) of these ecosystems. Indeed, SOM affects ecosystem sustainability by influencing many edaphic physical, chemical and biological characteristics [7]. To obtain short-term responses to the expected warming on soil organic $C$, microbiological and biochemical properties can be used as indicators because of their great sensitivity even to slight environmental modifications [8]. This is an important aspect to investigate as the activity of the soil microbial community strongly affects organic $C$ turnover $[9,10]$ and sequestration [11], influences several biogeochemical cycling of elements, and contributes to soil structure formation and stabilization [12].

In addition to soil moisture, temperature is the most important environmental factor affecting the heterotrophic microbial biomass and activity [13], enzymatic activity [14], and the related biochemical processes such as SOM decomposition [15]. Current soil C and models at Earth-system level estimate a positive and exponential relationship between soil microbial respiration and global warming [16,17]. The model outputs have been confirmed by meta-analyses of the data obtained by experimental warming in forest ecosystems $[18,19]$, which indicated that the boosted soil respiration is the result of increased enzymatic activities [20] and organic $C$ turnover. Temperature influences the kinetics of metabolic processes [21], and warming can increase the rate at which enzymes collide with, and breakdown, substrates. However, enzymes do not all have the same temperature sensitivity; for example, enzymes degrading more complex $C$ compounds may be more sensitive to temperature than those that degrade simple organic molecules [17,22]. Moreover, the temperature sensitivity of enzyme activity is also affected by the environmental conditions in which they are produced [23]. For example, enzymes released in soils of cold regions tend to have lower temperature optima than those produced in soils of warm environments [24].

Many studies were run on the influence of temperature on SOM cycling, but the obtained results were contrasting, possibly because the effect of temperature varied depending on the applied methods and the studied ecosystems. Among the different methodologies used to test the impact of temperature on soil properties, the climatic gradient that occurs over short distances in mountain slopes makes altitude a good proxy for understanding both the dynamic and steady-state response of forest soils to climate change. However, although many studies have been conducted along an altitudinal gradient e.g., [25-28], very few of them considered the same vegetation at different altitudes. An example of this is the study conducted on beech forests of the northern Apennines (Italy) by Vittori Antisari et al. [29], who found lower soil microbial respiration and metabolic quotient at higher altitude than at lower one, with greater chitinase, acid phosphatase and arylsulfatase activities at higher than at lower altitude. Another case is the study conducted on mixed pine and monospecific pine forests along an altitudinal gradient in the Cuenca Mountains, east-central Spain, by Lucas-Borja et al. [30], who found a general positive trend of the soil microbial and biochemical properties with altitude. To add knowledge about the influence of the temperature on soil microbial and biochemical properties, we explored European beech (Fagus sylvatica L.) forest soils of Apennine Mountains (central Italy) at two altitudes (800 and $1000 \mathrm{~m}$ ), using altitude as a proxy for temperature change. Specifically, on both organic and mineral soil horizons, we tested whether (i) organic $\mathrm{C}$ content increases with altitude; (ii) soil microbial biomass and activity, and enzymatic activity decrease with altitude. To verify these hypotheses, soil samples were analysed for total organic $C$, total nitrogen, water-extractable organic $C$, available $P$, microbial biomass $C$ and basal respiration, and the activities of nine enzymes.

\section{Materials and Methods}

\subsection{Study Sites}

The studied soils came from three calcareous massifs of the central Apennines chain (Italy): Mount Terminillo $\left(42^{\circ} 28^{\prime} \mathrm{N}, 12^{\circ} 59^{\prime} \mathrm{E}\right)$, Mount San Vicino $\left(43^{\circ} 19^{\prime} \mathrm{N}, 13^{\circ} 03^{\prime} \mathrm{E}\right)$, and Mount Acuto $\left(43^{\circ} 28^{\prime} \mathrm{N}\right.$, $12^{\circ} 41^{\prime} \mathrm{E}$ ) (Figure 1). At each site, two European beech (Fagus sylvatica L.) forests were selected on the 
north-facing slope, at 800 and $1000 \mathrm{~m}$ above sea level (a.s.l.), and with an inclination ranging from $25^{\circ}$ to $40^{\circ}$. The mean annual air temperature (MAAT) and the mean annual precipitation (MAP) were recovered from the climatic data supplied by Centro Appenninico "C. Jucci" [31] for Mount Terminillo (1956-2014 series), and from Spina et al. [32] and Amici and Spina [33] for both Mount San Vicino and Mount Acuto (1950-2000 series). According to these data, the study areas at 800 and $1000 \mathrm{~m}$ had a MAAT of $10^{\circ} \mathrm{C}$ and $9{ }^{\circ} \mathrm{C}$, respectively. The MAP of each site was similar at the two altitudes and it was $1248 \mathrm{~mm}$ at Mount Terminillo, $825 \mathrm{~mm}$ at Mount San Vicino, and $1430 \mathrm{~mm}$ at Mount Acuto. As the only detailed temperature series updated to nowadays was that of Mount Terminillo, to take into consideration temperature anomalies of the last years in each study site, we measured air temperature from March 2014 to March 2016 by YSI thermistors associated with UTL-2 dataloggers (Geotest, Zollikofen, Switzerland). The means obtained by the two-year measurements were $0.2-0.4^{\circ} \mathrm{C}$ higher than those of the long series, in agreement with the data of the last two years of the Mount Terminillo series (2013 and 2014) and with the reports of Pasquale et al. [34] and Desiato et al. [35]. However, the MAAT difference between 800 and $1000 \mathrm{~m}$ remained about $1^{\circ} \mathrm{C}$. Concerning temperature anomalies, in the years 2003, 2012 and 2015, the study sites experienced very warm and dry summers, but their effect on the soil can be considered as similar at both 800 and $1000 \mathrm{~m}$. All the soils had a mesic soil temperature regime and an udic soil moisture regime.

The selected forests were coppices in conversion, with the conversion that started from about 20 to 40 years ago. The most recent conversions occurred at $800 \mathrm{~m}$ at Mount Terminillo and at $1000 \mathrm{~m}$ at Mount San Vicino, while the oldest conversions started at $1000 \mathrm{~m}$ at Mount Terminillo and at both altitudes of Mount Acuto. At all sites, beech was the dominant tree, always representing more than $80 \%$ of the forest composition. The soil cover due to understory ranged from 5 to $50 \%$, with scarce to null signs of erosion. In fact, the soil coverage due to litter was always complete.

A detailed physiographic and climatic description of each site is reported in Table S1 of the Supplementary Materials.

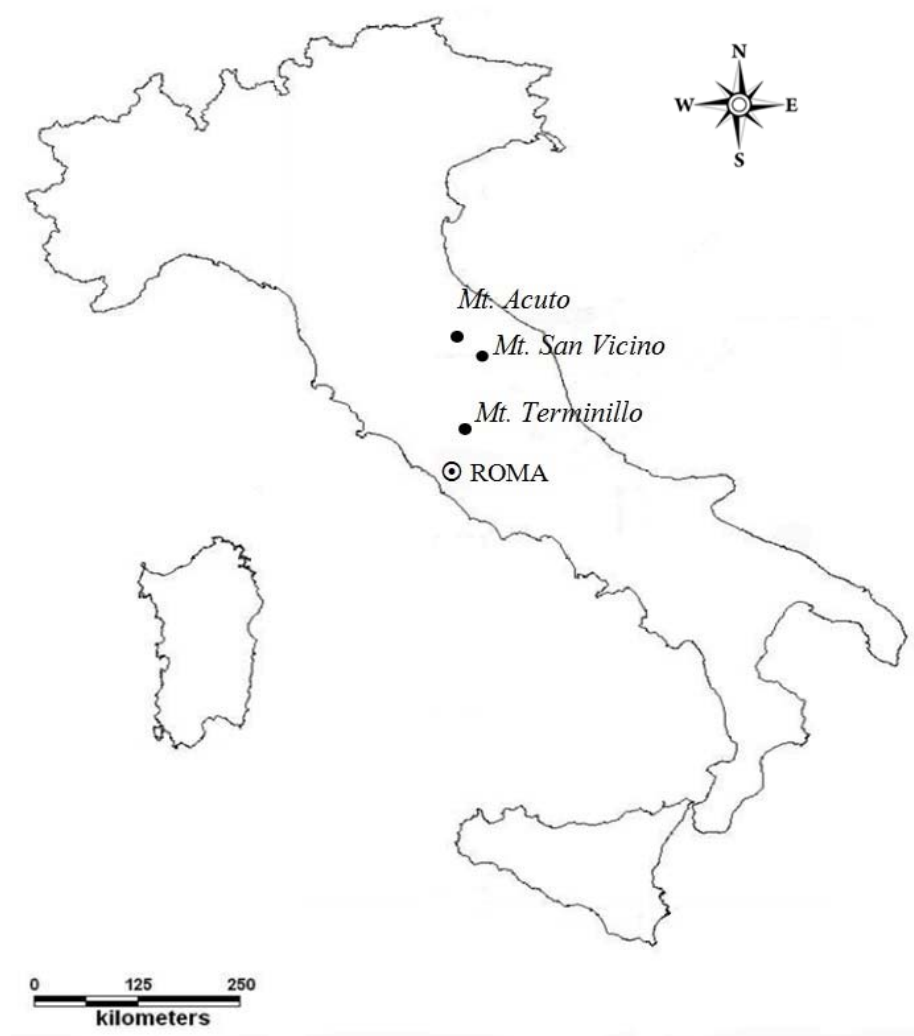

Figure 1. Map of Italy indicating the study sites in central Apennines, Italy. 


\subsection{Soils and Soil Sampling}

During the first decade of March 2014, two soil profiles were dug within a plot of about $100 \mathrm{~m}^{2}$ at each altitudinal site, for a total of 12 profiles ( 2 profiles $\times 2$ altitudes $\times 3$ calcareous massifs). Each profile was opened at about 50-60 $\mathrm{cm}$ from the stem of selected beech trees and morphologically described per Schoeneberger et al. [36]. Morphological observations of the profiles are given in Table S1 of the Supplementary Materials. Here, it suffices to recollect that the thickness of the O horizons in the soils at $800 \mathrm{~m}$ ranged from 5 to $10 \mathrm{~cm}$, while at $1000 \mathrm{~m}$ the range was from 5 to $17 \mathrm{~cm}$. The organic layer rested on mollic A horizons that in most cases were sufficiently thick to allow the soils to be classified as Mollisols according to Soil Survey Staff [37]. In particular, at $1000 \mathrm{~m}$, all the soils belonged to the order of Mollisols, while at $800 \mathrm{~m}$ three out of six soils had a too thin mollic horizon and were classified as Inceptisols because of the presence of a sufficiently thick cambic Bw horizon. In all cases, the A horizons showed a moderately to strongly developed structure made of crumbs or sub-angular blocks, while the horizons underneath displayed a less developed structure made of sub-angular and/or angular blocks. The OLv and $\mathrm{OH}$ horizons hosted the majority of mycelium, and only in one case (a soil at $800 \mathrm{~m}$ from Mount San Vicino) was mycelium also observed in the A horizon. The thickness of the solum (A+B horizons) ranged from 19 to $108 \mathrm{~cm}$ in the soils at $800 \mathrm{~m}$, and from 24 to $76 \mathrm{~cm}$ in the soils at $1000 \mathrm{~m}$. Analyses were run on all the organic horizons and on the mineral horizons until the first two Bw horizons.

From each soil horizon, a large amount of sample (0.27-0.9 kg for the organic horizons, and about $2 \mathrm{~kg}$ for the mineral ones) was collected and stored in a portable refrigerator. Once in the laboratory, an aliquot of each sample was stored at $4{ }^{\circ} \mathrm{C}$ for biochemical analysis, while the rest was allowed to air-dry. Then, about one-half of each dried organic sample was left in natural conditions, while the other half was triturated to pass a $1 \mathrm{~mm}$ sieve; the mineral samples were deprived of the visible roots under a magnifying lens and sieved with a 2-mm mesh.

\subsection{Chemical Analysis}

The $\mathrm{pH}$ was determined potentiometrically in water with a solid:liquid (w:v) ratios of 1:8 for the organic horizons (non-triturated samples) and 1:2.5 for the mineral horizons. Total organic C (TOC) content was estimated by $\mathrm{K}$-dichromate digestion, heating the suspension at $180{ }^{\circ} \mathrm{C}$ for $30 \mathrm{~min}$ [38]. Total N (TN) content was determined by a Carlo Erba EA1110 dry combustion analyzer (Carlo Erba Instruments, Milano, Italy). Water-extractable organic C (WEOC) was obtained according to Agnelli et al. [39] with the following procedure: $1 \mathrm{~g}$ of sample was placed into a plastic container, submerged with distilled water (solid:liquid ratio 1:10) and shaken overnight with an orbital shaker (140 rpm). The suspension was centrifuged at $1400 \mathrm{~g}$ for $10 \mathrm{~min}$, and then filtered through a $0.45 \mu \mathrm{m}$ membrane filter. The resulting solution was analyzed with a TOC-500A analyzer (Shimatzu, Kyoto, Japan) after the addition of a few drops of concentrated $\mathrm{H}_{3} \mathrm{PO}_{4}$ to eliminate carbonates. For the determination of TOC, TN and WEOC contents of the organic horizons, we used triturated samples. Available P was estimated only in the mineral horizons according to Olsen et al. [40].

\subsection{Biochemical Analysis}

The amount of microbial biomass-C (Cmic) was determined by the fumigation-extraction method [41], after the samples were conditioned for 50 days at $25{ }^{\circ} \mathrm{C}$ and at $50 \%$ of the total water holding capacity. Briefly, each soil sample (for the organic horizons, we used non-triturated samples) was exposed to alcohol-free chloroform $\left(\mathrm{CHCl}_{3}\right)$ vapor in a vacuum desiccator at $25{ }^{\circ} \mathrm{C}$ for $24 \mathrm{~h}$. Then, $\mathrm{CHCl}_{3}$ was removed from the fumigated soils by repeated evacuations. The fumigated and not-fumigated samples were extracted by shaking for $30 \mathrm{~min}$ with $0.5 \mathrm{M} \mathrm{K}_{2} \mathrm{SO}_{4}$ (solid:liquid ratio 1:4). The extracted organic $\mathrm{C}$ was measured by oxidation with $\mathrm{K}$-dichromate and a subsequent back-titration of the unreduced dichromate [41]. During the incubation period, basal respiration was measured by alkali (1 $\mathrm{M} \mathrm{NaOH}$ solution) absorption of the $\mathrm{CO}_{2}$ developed and titration of the residual $\mathrm{OH}^{-}$with a 
standardized $\mathrm{HCl}$ solution. Basal respiration was expressed as the cumulative amount of $\mathrm{CO}_{2}-\mathrm{C}$ that evolved during the experiment $\left(\Sigma \mathrm{CO}_{2}-\mathrm{C}\right)$.

Enzymes were desorbed by heteromolecular exchange using an excess of exogenous protein [42], and enzymatic activity was quantified according to Cowie et al. [43]. Briefly, $150 \mathrm{mg}$ of non-triturated sample for the organic horizons and $250 \mathrm{mg}$ of sample for the mineral horizons were placed in a 2-mL Eppendorf tube with glass beads and $1.2 \mathrm{~mL}$ of $50 \mathrm{mM}$ tris- $\mathrm{HCl}$ solution at $\mathrm{pH} 7.0$, containing $2 \%$ lysozyme as a desorbing protein. The tube was subjected to bead-beating ( $3 \mathrm{~min}, 30$ strokes s$^{-1}$ ) using a Retsch MM400 mill (Retsch, Haan, Germany), and then centrifuged for 5 min at 20,000 g. Enzymatic activity was assayed fluorometrically in microplates using 4-methyl-umbelliferyl and 7-amino-4-methyl coumarine conjugated surrogate substrates (Sigma, St Louis, MO, USA). The activity of cellulase, xylosidase, $\beta$-glucosidase, chitinase, acid phosphomonoesterase, and arylsulfatase was determined in $200 \mathrm{mM}$ MES (morpholineptansulfonic acid) solution at $\mathrm{pH}$ 5.8; the activity of alkaline phosphomonoesterase was determined in $100 \mathrm{mM}$ tris- $\mathrm{HCl}$ solution at $\mathrm{pH} 9.0$, and that of acetate esterase and leucine aminopeptidase in $100 \mathrm{mM}$ tris- $\mathrm{HCl}$ solution at $\mathrm{pH}$ 7.5.

\subsection{Statistical Analysis}

To assess differences among horizons at the two altitudes, the results of each horizon were averaged with those of the similar horizon at $800 \mathrm{~m}$, and the same was done for those at $1000 \mathrm{~m}$. However, to obtain solid horizon averages, for the soils where the $A B$ horizons were absent (Mount Terminillo), we considered as $\mathrm{AB}$ the $\mathrm{A} 2$ horizon of a soil at $800 \mathrm{~m}$ and one at $1000 \mathrm{~m}$; the $2 \mathrm{Ab}$ horizon of a soil at $1000 \mathrm{~m}$ from Mount Acuto was averaged with the above AB horizon. Hence, for both $\mathrm{A}$ and $\mathrm{AB}$ horizons, the results of each couple of profiles at the three sites were averaged, and these averages were used to calculate the mean for both altitudes $(n=3)$. Additionally, for the Bw horizons, we had to adjust few situations. At Mount Terminillo, soil was shallow both at 800 and $1000 \mathrm{~m}$, where no Bw horizon was present; for this site, only the Bw1 and Bw2 horizons of one profile per altitude were considered. At Mount San Vicino, one of the soils at $1000 \mathrm{~m}$ showed a Bw and a 2Bwb horizon, which were considered as Bw1 and Bw2, respectively. At Mount Acuto, one soil at $1000 \mathrm{~m}$ had a $2 \mathrm{Bwb}$ horizon that was considered as a Bw1, while the underneath $3 \mathrm{Ab}$ and $3 \mathrm{Bwb}$ were averaged and considered as Bw2 horizon. After these adjustments, also for Bw1 and Bw2 horizons, a mean for both altitudes was calculated for $n=3$.

Two-way ANOVA was performed to assess the effect of altitude and soil horizons on the soil properties. Graphical analyses of residuals were used to ensure that the basic assumptions for linear models were met; otherwise, the data were transformed according to the maximum likelihood procedure suggested by Box and Cox [44]. The results presented are based on mean values and their standard error, and the significance of differences between means was assessed by using Fisher's least significant difference (LSD) post-hoc test $(p<0.05)$. The data were analyzed using R software [45].

Non-metric multidimensional scaling (NMDS) performed by using the R package "vegan" with the dissimilarity matrix calculated by the Gower's distance was used to provide a graphical representation of results for both organic (Stress $=0.105$ ) and mineral (Stress $=0.100$ ) horizons. For this analysis, data were standardized by subtracting the mean and dividing by the standard deviation.

\section{Results}

\subsection{Chemical Properties}

For the soils at $800 \mathrm{~m}, \mathrm{pH}$ ranged from 6.27 to 7.02 , with no substantial difference among the horizons (Table 1). At $1000 \mathrm{~m}, \mathrm{pH}$ ranged from 6.08 to 7.75 and few mineral horizons showed $\mathrm{pH}$ values higher than those of the organic ones. Differences between horizons at the two altitudes occurred only for the sub-superficial horizons (AB, Bw1 and Bw2). At the two altitudes, both TOC and TN contents were much higher in the organic than in the mineral horizons (Table 1). As expected, the two parameters tended to decrease with depth at both altitudes. TOC and TN were similar in the 
organic horizons at 800 and $1000 \mathrm{~m}$, while they were higher in the mineral horizons at 1000 than at $800 \mathrm{~m}$. The concentration of WEOC showed no variation with depth and between altitudes, with the only exception of the OLn horizon at $1000 \mathrm{~m}$, which showed the lowest value. The available P content tended to decline with depth at both altitudes, and was greater in the sub-superficial horizons ( $A B$, Bw1 and Bw2) of the soils at 1000 than in those at $800 \mathrm{~m}$.

\subsection{Microbial Biomass C Content, Basal Respiration and Enzymatic Activity}

At low and high altitude, both $\mathrm{Cmic}$ content and $\Sigma \mathrm{CO}_{2}-\mathrm{C}$ were markedly higher in the organic than in the mineral horizons, and tended to decrease from OLn to OH horizon (Table 2). In the mineral horizons, Cmic decreased with depth only in the soils at $800 \mathrm{~m}$, while at $1000 \mathrm{~m}$ it exhibited similar values along the whole soil profiles. Concerning $\Sigma \mathrm{CO}_{2}-\mathrm{C}$, in the mineral horizons at $800 \mathrm{~m}$ it decreased with depth from $1984 \mathrm{mg} \mathrm{kg}^{-1}$ (A horizon) to $265 \mathrm{mg} \mathrm{kg}^{-1}$ (Bw2 horizon), but because samples were small, the difference was not statistically significant. At $1000 \mathrm{~m}, \Sigma \mathrm{CO}_{2}-\mathrm{C}$ was similar in all the mineral horizons.

By contrasting the two biochemical parameters horizon by horizon, only $\mathrm{Cmic}$ differed in the sub-superficial horizons (AB, Bw1 and Bw2), with larger values at 1000 than at $800 \mathrm{~m}$.

The activities of most of the enzymes showed the highest values in the OLn horizon and decreased with increasing depth, both within organic and mineral horizons (Table 3). The only exception to this trend was represented by the arylsulfatase activity, which increased at both altitudes from the OLn horizon to the A horizon, to remain rather constant with increasing depth except for the Bw2 horizon at $800 \mathrm{~m}$ where it reduced significantly. By contrasting horizon by horizon, the enzymatic activities were generally similar at 800 and $1000 \mathrm{~m}$, although some exceptions occurred. In particular, in the organic horizons at $1000 \mathrm{~m}$, cellulase showed lower activity in the OLv and OH horizons, while the alkaline phosphomonoesterase activity was higher in the OLn horizon. In the mineral soil, alkaline phosphomonoesterase showed greater activity in the sub-superficial horizons (AB, Bw1, Bw2) at $1000 \mathrm{~m}$, whereas xylosidase, $\beta$-glucosidase, arylsulfatase and leucine-aminopeptidase displayed, in general, major activities in the deeper horizons of the soils at $1000 \mathrm{~m}$. 
Table 1. $\mathrm{pH}$ values and contents of total organic carbon (TOC), total nitrogen (TN), water extractable organic carbon (WEOC) and available $\mathrm{P}$ of the soils under Fagus sylvatica forests at two altitudes (low: $800 \mathrm{~m}$; high: $1000 \mathrm{~m}$ ), Central Apennines, Italy. Numbers in parentheses are the standard errors $(n=3)$. For each parameter, mean values with different letters significantly differ for $p<0.05$.

\begin{tabular}{|c|c|c|c|c|c|c|c|c|c|c|}
\hline \multirow[t]{2}{*}{ Horizons } & \multicolumn{2}{|c|}{$\mathrm{pH}$} & \multicolumn{2}{|c|}{ TOC } & \multicolumn{2}{|c|}{ TN } & \multicolumn{2}{|c|}{ WEOC } & \multicolumn{2}{|c|}{ Available P } \\
\hline & Low & High & Low & High & Low & High & Low & High & Low & High \\
\hline & \multicolumn{8}{|c|}{$\mathrm{g} \mathrm{kg}^{-1}$} & \multicolumn{2}{|c|}{$\mathrm{mg} \mathrm{kg}^{-1}$} \\
\hline OLn & $6.28(0.11) \mathrm{de}$ & $6.08(0.05) \mathrm{e}$ & $468.42(28.56) \mathrm{ab}$ & $540.55(11.48) \mathrm{a}$ & $12.51(0.94) b$ & $16.13(1.20) a b$ & $0.19(0.07) \mathrm{ac}$ & $0.09(0.04) \mathrm{c}$ & nd & nd \\
\hline OLv & $6.33(0.10)$ ce & $6.68(0.13) b c$ & $462.19(27.70) \mathrm{ab}$ & $527.29(15.51)$ a & $14.64(0.74) \mathrm{ab}$ & $17.14(0.64) \mathrm{a}$ & $0.25(0.03) \mathrm{ab}$ & $0.16(0.06) b c$ & nd & nd \\
\hline $\mathrm{OH}$ & $7.02(0.21)$ ac & $6.78(0.30) \mathrm{ad}$ & $387.70(42.93) b$ & $424.90(16.04) \mathrm{b}$ & $16.52(2.01) \mathrm{ab}$ & $18.61(1.89)$ a & $0.30(0.14) \mathrm{ab}$ & $0.29(0.10) \mathrm{ab}$ & nd & nd \\
\hline A & $6.94(0.30)$ be & $7.33(0.22) \mathrm{ab}$ & $71.36(6.57) \mathrm{d}$ & 95.79 (15.24) c & $3.47(0.53) \mathrm{d}$ & $8.22(1.00) \mathrm{c}$ & $0.33(0.02) \mathrm{ab}$ & $0.32(0.05) \mathrm{a}$ & $17.7(1.9) \mathrm{ab}$ & $20.2(1.0) \mathrm{a}$ \\
\hline $\mathrm{AB}$ & $6.77(0.48)$ be & $7.72(0.15) \mathrm{a}$ & $40.26(5.83) \mathrm{e}$ & $62.27(8.90) \mathrm{d}$ & $2.86(0.63) \mathrm{e}$ & $5.44(0.77) \mathrm{d}$ & $0.30(0.03) \mathrm{ab}$ & $0.23(0.03) \mathrm{ab}$ & $11.0(2.1) \mathrm{cd}$ & $15.8(1.0) \mathrm{b}$ \\
\hline Bw1 & $6.27(0.33)$ de & $7.50(0.12) \mathrm{ab}$ & $22.41(4.11) \mathrm{f}$ & $62.38(3.20) \mathrm{d}$ & $1.14(0.08) \mathrm{f}$ & $5.61(0.37) \mathrm{cd}$ & $0.31(0.06) \mathrm{ab}$ & $0.19(0.03) \mathrm{ac}$ & $8.0(1.8) \mathrm{d}$ & 15.0 (1.4) bc \\
\hline Bw2 & $6.63(0.45)$ be & $7.75(0.02) \mathrm{a}$ & $12.64(1.19) \mathrm{g}$ & 52.79 (2.55) de & $1.04(0.11) \mathrm{f}$ & $5.43(2.28) \mathrm{d}$ & $0.20(0.02) \mathrm{ac}$ & $0.18(0.01) \mathrm{ac}$ & $7.5(1.6) d$ & $12.7(0.3) b c$ \\
\hline
\end{tabular}

Table 2. Content of microbial biomass $\mathrm{C}$ (Cmic), and amount of $\mathrm{CO}_{2}$ evolved during basal respiration experiments $\left(\Sigma \mathrm{CO}_{2}-\mathrm{C}\right)$ of the soils under Fagus sylvatica forests at two altitudes (low: 800 m; high: 1000 m). Central Apennines, Italy. Numbers in parentheses are the standard errors ( $n=3)$. For each parameter, mean values with different letters significantly differ for $p<0.05$.

\begin{tabular}{ccccc}
\hline Horizons & \multicolumn{2}{c}{ Cmic } & Low & High \\
\hline \multicolumn{7}{c}{ Low } & \multicolumn{2}{c}{$\mathbf{m g ~ k g}_{2}-\mathbf{C}$} \\
\hline OLn & $169.00(46.80) \mathrm{ab}$ & $302.37(17.98) \mathrm{a}$ & $18,539(3843) \mathrm{ab}$ & $20,088(1993) \mathrm{a}$ \\
OLv & $189.60(47.76) \mathrm{a}$ & $108.41(23.25) \mathrm{ab}$ & $14,082(2731) \mathrm{bc}$ & $12,967(1772) \mathrm{cd}$ \\
OH & $56.99(33.19) \mathrm{b}$ & $186.51(27.08) \mathrm{ab}$ & $8128(2023) \mathrm{de}$ & $7073(1869) \mathrm{e}$ \\
$\mathrm{A}$ & $0.07(0.01) \mathrm{cd}$ & $0.19(0.02) \mathrm{c}$ & $1984(561) \mathrm{f}$ & $697(67) \mathrm{f}$ \\
$\mathrm{AB}$ & $0.07(0.02) \mathrm{de}$ & $0.19(0.02) \mathrm{c}$ & $768(276) \mathrm{f}$ & $421(84) \mathrm{f}$ \\
Bw1 & $0.03(0.01) \mathrm{ef}$ & $0.19(0.01) \mathrm{c}$ & $308(117) \mathrm{f}$ & $584(323) \mathrm{f}$ \\
Bw2 & $0.02(0.01) \mathrm{f}$ & $0.12(0.06) \mathrm{cd}$ & $265(93) \mathrm{f}$ & $480(57) \mathrm{f}$ \\
\hline
\end{tabular}


Table 3. Soil enzymatic activities of the soils under Fagus sylvatica forests at two altitudes (low: $800 \mathrm{~m}$; high: $1000 \mathrm{~m}$ ). Central Apennines, Italy. Numbers in parentheses are the standard deviations $(n=3)$. For each parameter, mean values with different letters significantly differ for $p<0.05$.

\begin{tabular}{|c|c|c|c|c|c|c|c|c|c|}
\hline Horizons & Cell & Xylo & $\beta$-Gluco & Chit & AcPME & AlkPME & AcEst & Aryls & Leu \\
\hline & \multicolumn{9}{|c|}{ Nanomoles of 4-methylumbelliferone (7-amino-4-methyl coumarine) $\cdot \mathrm{g}^{-1}$ dry soil $\cdot$ hour $^{-1}$} \\
\hline \multicolumn{10}{|c|}{ Low Altitude $(800 \mathrm{~m})$} \\
\hline OLn & $71.3(25.1) \mathrm{a}$ & $54.5(11.6) \mathrm{a}$ & $509.1(142.4) \mathrm{a}$ & 196.8 (25.6) a & 408.1 (116.8) a & $294.5(49.7) \mathrm{b}$ & $3278.8(258.0) \mathrm{ab}$ & $6.5(1.8) \mathrm{d}$ & $335.4(54.8) \mathrm{a}$ \\
\hline OLv & $38.3(11.7) \mathrm{b}$ & $35.2(5.2) \mathrm{ab}$ & $215.8(82.2) b$ & 134.5 (15.4) ab & $291.1(43.1)$ ac & $318.9(64.5) \mathrm{b}$ & $3421.3(239.8) \mathrm{ab}$ & $8.7(2.4) \mathrm{cd}$ & $357.0(511.9) \mathrm{a}$ \\
\hline $\mathrm{OH}$ & $4.4(1.5) \mathrm{d}$ & $6.8(2.2) \mathrm{c}$ & $34.1(15.2) \mathrm{c}$ & $38.6(5.1) \mathrm{d}$ & 129.1 (21.3) de & $362.9(62.6) \mathrm{ab}$ & $1807.3(548.0) \mathrm{cd}$ & $19.4(8.9) \mathrm{b}$ & $110.0(29.0) \mathrm{b}$ \\
\hline A & $0.2(0.1)$ ef & $1.2(0.2) \mathrm{d}$ & $5.1(0.6) \mathrm{d}$ & $5.6(1.7) \mathrm{e}$ & $105.4(11.1) \mathrm{df}$ & $143.7(17.7) \mathrm{cd}$ & $1810.9(358.0) \mathrm{c}$ & $67.5(5.6) \mathrm{a}$ & $25.6(2.3) \mathrm{d}$ \\
\hline $\mathrm{AB}$ & $0.1(0.0) \mathrm{f}$ & $0.6(0.1) \mathrm{e}$ & $2.3(0.2) \mathrm{e}$ & 3.4 (1.6) ef & 72.0 (15.4) eg & $66.4(41.7) \mathrm{d}$ & $1074.1(345.5) \mathrm{df}$ & $86.84(31.4)$ a & $14.1(2.8) \mathrm{d}$ \\
\hline Bw1 & $0.0(0.0) \mathrm{f}$ & $0.4(0.1)$ ef & $0.8(0.2) \mathrm{fg}$ & $1.0(0.2) \mathrm{fg}$ & $47.8(11.8) \mathrm{gh}$ & $11.3(6.1) \mathrm{e}$ & $777.6(197.3) \mathrm{f}$ & $56.4(18.0)$ a & $5.7(0.7) \mathrm{e}$ \\
\hline Bw2 & $0.0(0.0) \mathrm{f}$ & $0.2(0.0) \mathrm{f}$ & $0.5(0.2) \mathrm{g}$ & $0.7(0.2) \mathrm{g}$ & $32.3(9.9) \mathrm{h}$ & $20.4(10.6)$ e & $578.8(195.6) \mathrm{f}$ & $26.0(5.2) \mathrm{b}$ & $4.3(1.3) \mathrm{e}$ \\
\hline \multicolumn{10}{|c|}{ High Altitude $(1000 \mathrm{~m})$} \\
\hline OLn & $96.6(23.6) \mathrm{a}$ & $63.7(6.8) \mathrm{a}$ & 581.7 (106.3) а & $202.8(32.0) \mathrm{a}$ & $338.3(16.2) \mathrm{ab}$ & $456.0(70.0)$ a & 4143.1 (301.6) a & $7.3(1.8) \mathrm{cd}$ & $364.6(60.5) \mathrm{a}$ \\
\hline OLv & $15.8(4.7) \mathrm{c}$ & $20.5(3.5) b$ & $118.0(32.2) b$ & $92.6(21.28) b c$ & $236.9(42.5) \mathrm{bc}$ & 408.6 (48.6) ab & $2741.4(354.7) b$ & $13.7(3.3) b c$ & $280.4(95.2)$ a \\
\hline $\mathrm{OH}$ & $0.8(1.0) \mathrm{e}$ & $3.8(2.1) \mathrm{c}$ & $17.2(8.6) \mathrm{c}$ & $50.7(15.4) \mathrm{cd}$ & $175.1(28.8) \mathrm{cd}$ & $278.5(35.5) \mathrm{b}$ & 1372.8 (212.3) ce & $25.8(9.1) \mathrm{b}$ & $73.7(10.1) b c$ \\
\hline A & $0.0(0.0) \mathrm{f}$ & $0.5(0.2) \mathrm{e}$ & $3.3(0.6) \mathrm{de}$ & $2.5(0.9)$ ef & $70.3(10.5) \mathrm{fg}$ & 165.3 (20.4) bc & $1000.2(232.3)$ ef & $62.7(4.0) \mathrm{a}$ & $19.2(5.2) \mathrm{d}$ \\
\hline $\mathrm{AB}$ & $0.0(0.0) \mathrm{f}$ & $0.3(0.2)$ ef & $2.0(0.6)$ ef & $2.4(1.1) \mathrm{f}$ & $46.7(9.6) \mathrm{gh}$ & $115.3(7.8) \mathrm{c}$ & $660.5(173.4) \mathrm{f}$ & $62.0(11.5) \mathrm{a}$ & $17.5(7.5) \mathrm{d}$ \\
\hline Bw1 & $0.1(0.0)$ ef & $0.8(0.4) \mathrm{de}$ & $3.1(0.8) \mathrm{de}$ & 3.4 (3.1) ef & 57.6 (10.5) fh & $104.5(29.3) \mathrm{cd}$ & $935.5(422.0)$ ef & $77.4(20.5) \mathrm{a}$ & $30.7(18.7) \mathrm{cd}$ \\
\hline Bw2 & $0.1(0.1)$ ef & $0.7(0.6) \mathrm{de}$ & $2.1(1.2)$ ef & $2.3(2.2) \mathrm{fg}$ & 42.9 (21.6) gh & $82.8(30.0) \mathrm{cd}$ & $731.9(552.0) \mathrm{f}$ & $82.4(19.6)$ a & $21.7(17.5) \mathrm{d}$ \\
\hline
\end{tabular}

Cell = cellulase; Xylo = xylosidase; $\beta$-Gluco = $\beta$-glucosidase; Chit = chitinase; AcPME = acid phosphomonoesterase; AlkPME = alkaline phosphomonoesterase; AcEst = acetate esterase; AryS $=$ arylsulfatase; Leu $=$ leucine aminopeptidase. 


\subsection{Non-Metric Multidimensional Scaling Analysis}

NMDS analysis provided substantial similarity between chemical and biochemical characteristics of the organic horizons at 800 and $1000 \mathrm{~m}$, as indicated by the almost complete overlapping of the confidence ellipses (Figure 2a). Conversely, NMDS analysis performed on the mineral horizons (Figure 2b) grouped the data into two clusters according to the different altitudes. The separation of the two groups occurred along the axis 1 which appeared to be mainly driven by the contents of TOC and $\mathrm{Cmic}$, the $\Sigma \mathrm{CO}_{2}-\mathrm{C}$, and the activities of $\beta$-glucosidase, cellulase, xylosidase and phosphomonoesterase.

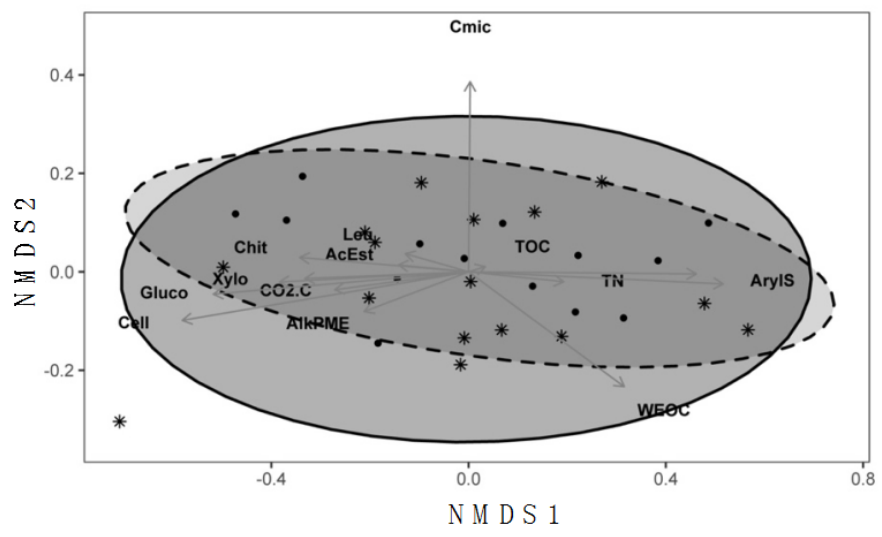

a)

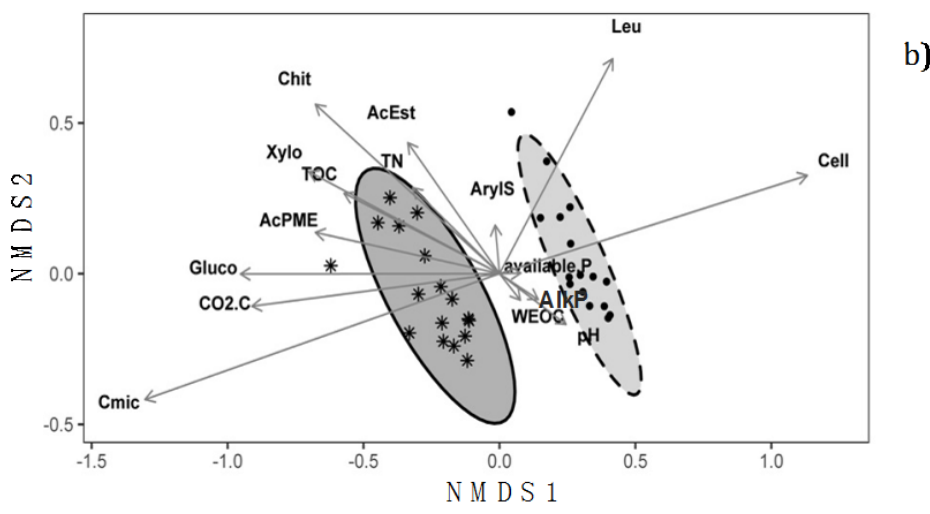

b)

Figure 2. Non-metric multidimensional scaling (NMDS) plots showing the similarity/dissimilarity among (a) organic; and (b) mineral horizons between the soils under Fagus sylvatica forests at the two altitudes of $800 \mathrm{~m}$ and $1000 \mathrm{~m}$ in central Apennines, Italy. The drawn ellipses are at $95 \%$ confidence. (Legend: TOC: total organic carbon; TN: total nitrogen; WEOC: water extractable organic carbon; available P: available phosphorus; $\mathrm{Cmic}$ : microbial biomass carbon; $\mathrm{CO}_{2}-\mathrm{C}: \mathrm{CO}_{2}$ evolved during basal respiration experiments; Cell: cellulase; Xylo: xylosidase; Gluco: $\beta$-glucosidase; Chit: chitinase; AcPME: acid phosphomonoesterase; AlkPME: alkaline phosphomonoesterase, AcEst: acetate esterase; ArylS: arylsulfatase; Leu: leucine aminopeptidase).

\section{Discussion}

Altitude did not affect the soil $\mathrm{pH}$ of the organic horizons and of the upper part of the mineral soil (A horizon), but produced significant differences in the deeper horizons. The higher $\mathrm{pH}$ values of the $\mathrm{AB}, \mathrm{Bw} 1$ and Bw2 horizons at $1000 \mathrm{~m}$ than at $800 \mathrm{~m}$ were attributed to a lower rate of chemical weathering and decarbonation that occur in the mountain soils with increasing altitude $[46,47]$. The greater TOC and TN contents in the mineral soil at higher altitude were mostly considered a consequence of the lower mean temperature [48] that, despite reducing the production of plant biomass, lowers the soil microbial activity [49-52]. However, this effect was not visible in the OLn, 
OLv and $\mathrm{OH}$ horizons where TOC and TN concentrations did not change among the layers (with the exception of the $\mathrm{OH}$ horizon at $1000 \mathrm{~m}$ ) and at the two altitudes. With regard to the altitude effect, the lack of significant differences in TOC and TN contents in the organic horizons at the two altitudes was attributed to the morphological variability among the study sites that spanned about $1^{\circ}$ latitude along the Apennine chain. Conversely to TOC, WEOC content did not differ between the soils at 800 and $1000 \mathrm{~m}$. Because of this, the lower WEOC/TOC ratios in the mineral horizons at $1000 \mathrm{~m}$ (Figure 3) were evidently due to a higher content of organic matter as a consequence of the lower mean temperature [47].

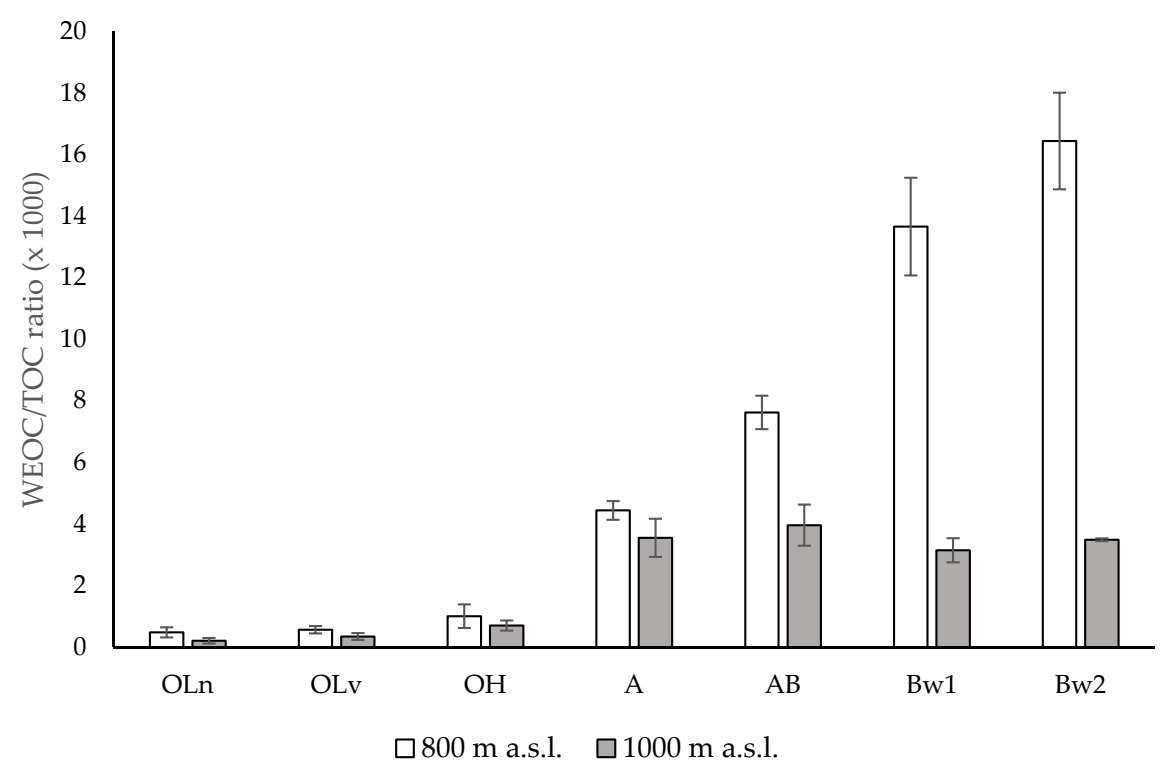

Figure 3. WEOC/TOC ratio of the different horizons along the soils under Fagus sylvatica forests at two altitudes, $800 \mathrm{~m}$ and $1000 \mathrm{~m}$ above sea level (a.s.l.), central Apennines, Italy. Error bars are the standard errors $(n=3)$.

With regard to Cmic content, while organic horizons did not show significant differences between 800 and $1000 \mathrm{~m}$, the mineral horizons had more abundant microbial biomass in the sub-superficial horizons (AB, Bw1, Bw2) at $1000 \mathrm{~m}$. This latter fact, together with the similar $\Sigma \mathrm{CO}_{2}-\mathrm{C}$ released during the incubation experiment, would confirm the low efficiency of the microbial community at higher altitude [51]. The lack of effect of the altitude on the organic horizons for both microbial biomass and respiration may be due to the large availability of microbes of easily degradable substances that occurs in the organic layer. Therefore, the low energetic requirements needed by the microbial community of the $\mathrm{O}$ horizons to have access to degradable substrates could mitigate the low thermic constraints $\left(1{ }^{\circ} \mathrm{C}\right)$ of the soils at $1000 \mathrm{~m}$ with respect to those at $800 \mathrm{~m}$. Conversely, the reduction of SOM content and its increasing recalcitrance with depth [53] in the mineral horizons with respect to the organic layers made the microbial community more sensitive to the changes occurring at $1000 \mathrm{~m}$ because of the lower temperature. In fact, although the thermal damping increases with depth, the microbial community in the deeper horizons partly depends on the easily available substances produced by the degradation processes of the litter layer, which is more exposed to environmental constraints.

In general, although the influence of other factors on soil biogeochemical processes due to the above and belowground heterogeneity cannot be excluded, $1{ }^{\circ} \mathrm{C}$ of temperature difference between the sites at 800 and $1000 \mathrm{~m}$ seemed to have little effect on the soil enzymatic activity, especially in the organic horizons. The only two enzymes that showed sensitivity to the altitude in the organic horizons were cellulase and alkaline phosphomonoesterase. The reduced activity of cellulase in the OLv and $\mathrm{OH}$ horizons at $1000 \mathrm{~m}$ with respect to those at $800 \mathrm{~m}$, could be due to the high temperature sensitivity of C-degrading enzymes [54] and to the fact that enzymes that degrade complex compounds (such as 
cellulose) are more sensitive to temperature than enzymes degrading simple molecules [20,21]. The low cellulase activity might have caused a decrease in the $C$ use efficiency of the decomposer $[55,56]$ and, hence, reduced the rate of decomposition of the organic residue and increased the soil $\mathrm{C}$ content at high altitude. The greater activity at $1000 \mathrm{~m}$ than at $800 \mathrm{~m}$ of the alkaline phosphomonoesterase all along the mineral horizons, other than in the OLn horizon, further supported the general higher amount of available P occurring in the soils at higher altitude. The larger TOC content $[57,58]$ and the higher $\mathrm{pH}$ [59] of the soils at greater elevation were considered the main factors able to foster the alkaline phosphomonoesterase activity. Further, the higher enzymatic activities (xylosidase, $\beta$-glucosidase, alkaline phosphomonoesterase, arylsulfatase and leucine aminopeptidase) found in the deeper mineral horizons might be due more to plant roots than to the microbial community, which strongly decreases with increasing soil depth. Indeed, plant roots are also responsible for the soil enzyme production, both by direct release of the enzymes $[59,60]$ and by enhancing the microbial activity through rhizodeposition processes [61]. In this regard, we hypothesize that, as a response to climatic constraints occurring at higher altitude, plants may release low molecular weight organic substances [62] able to fuel the activity of the soil microbial community [63] and stimulate the enzymes production.

\section{Conclusions}

In this work, we evaluated the effect of altitude, and consequently of temperature, on the chemical and biochemical properties of beech forest soils along the Apennine chain (Italy). The analytical results and the NMDS analysis showed that $1{ }^{\circ} \mathrm{C}$ of mean annual temperature difference between the sites at $800 \mathrm{~m}$ and $1000 \mathrm{~m}$ a.s.l. had a greater effect on the mineral horizons than on the organic ones, which are more exposed to environmental constraints. Indeed, the lower mean temperature occurring at $1000 \mathrm{~m}$ was responsible for a reduced soil weathering, as suggested by the limited profile development and higher $\mathrm{pH}$, and a general lower organic decomposition, as indicated by the greater concentration of TOC and TN in the mineral horizons but not in the organic horizons. The biochemical data ( $\mathrm{Cmic}$ and $\Sigma \mathrm{CO}_{2}-\mathrm{C}$ ) partly supported these findings, indicating a general lower efficiency of the microbial community at higher altitude than at lower altitude. With regard to the enzymatic activities, in general, no statistically significant effect between the sites at $800 \mathrm{~m}$ and $1000 \mathrm{~m}$ was found in the organic horizons, possibly because of their large availability of easily degradable substances that, stimulating microrganisms, are able to mitigate the low thermic constraints. Conversely, significantly higher activity of some enzymes (xylosidase, $\beta$-glucosidase, alkaline phosphomonoesterase, arylsulfatase, and leucine aminopeptidase) in the Bw1 and Bw2 horizons of the soils at $1000 \mathrm{~m}$ was probably due to a production of enzymes directly and indirectly promoted by the roots of the plants found at this height.

Supplementary Materials: The following are available online at www.mdpi.com/1999-4907/8/6/213/s1, Table S1: General features and morphology of the soils under Fagus sylvatica L. at 800 and $1000 \mathrm{~m}$ of altitude for mountains of central Apennines (Italy).

Acknowledgments: The authors are indebted with Francesco Bigaran for field assistance.

Author Contributions: M.D.F., V.C., M.L., A.L., F.F. S.C., G.C. and A.A. conceived and designed the study; M.D.F., V.C., M.L., S.C., G.C. and A.A. collected the samples and performed the chemical analyses; A.L., F.F., D.J.W. performed the biochemical analyses; M.D.F., V.C., M.L. and A.A. analysed the data; M.D.F., V.C., M.L., A.L., F.F. S.C., G.C. and A.A. wrote the paper.

Conflicts of Interest: The authors declare no conflict of interest.

\section{References}

1. Intergovernmental Panel on Climate Change (IPCC). Summary for policymakers. In Climate Change 2013: The Physical Science Basis; Contribution of Working Group I to the Fifth Assessment Report of the Intergovernmental Panel on Climate Change; Stocker, T.F., Qin, D., Plattner, G.-K., Tignor, M., Allen, S.K., Boschung, J., Nauels, A., Xia, Y., Bex, V., Midgley, P.M., Eds.; Cambridge University Press: Cambridge, UK; New York, NY, USA, 2013; pp. 1-30. 
2. Giorgi, F.; Lionello, P. Climate change projections for the Mediterranean region. Glob. Planet. Chang. 2008, 63, 90-104. [CrossRef]

3. Piovesan, G.; Biondi, F.; Di Filippo, A.; Alessandrini, A.; Maugeri, M. Drought-driven growth reduction in old beech (Fagus sylvatica L.) forests of the central Apennines, Italy. Glob. Chang. Biol. 2008, 14, 1265-1281. [CrossRef]

4. Bonan, G.B. Forests and climate change: forcings, feedbacks, and the climate benefits of forests. Science 2008, 320, 1444-1449. [CrossRef] [PubMed]

5. Lal, R. Forest soils and carbon sequestration. Forest Ecol. Manag. 2005, 220, 242-258. [CrossRef]

6. Scarascia-Mugnozza, G.; Oswald, H.; Piussi, P.; Radoglou, K. Forests of the Mediterranean region: Gaps in knowledge and research needs. For. Ecol. Manag. 2000, 132, 97-109. [CrossRef]

7. Knoepp, J.D.; Coleman, D.C.; Crossley, D.A., Jr.; Clark, J.S. Biological indices of soil quality: An ecosystem case study of their use. For. Ecol. Manag. 2000, 138, 357-368. [CrossRef]

8. Gil-Sotres, F.; Trasar-Cepeda, C.; Leiros, M.C.; Seoane, S. Different approaches to evaluating soil quality using biochemical properties. Soil Biol. Biochem. 2005, 37, 877-887. [CrossRef]

9. Kögel-Knabner, I. The macromolecular organic composition of plant and microbial residues as inputs to soil organic matter. Soil Biol. Biochem. 2002, 34, 139-162. [CrossRef]

10. Ludwig, M.; Achtenhagen, J.; Miltner, A.; Eckhardt, K.-U.; Leinweber, P.; Emmerling, C.; Thiele-Bruhn, S. Microbial contribution to SOM quantity and quality in density fractions of temperate arable soils. Soil Biol. Biochem. 2015, 81, 311-322. [CrossRef]

11. Miltner, A.; Bombach, P.; Schmidt-Brücken, B.; Kästner, M. SOM genesis: Microbial biomass as a significant source. Biogeochemistry 2012, 111, 41-55. [CrossRef]

12. Lagomarsino, A.; Moscatelli, M.C.; Di Tizio, A.; Mancinelli, R.; Greco, S.; Marinari, S. Soil biochemical indicators as a tool to assess the short-term impact of agricultural management on changes in organic $\mathrm{C}$ in a Mediterranean environment. Ecol. Indic. 2009, 9, 518-527. [CrossRef]

13. Paul, E.A.; Clark, F.E. Soil Microbiology and Biochemistry, 2nd ed.; Academic Press: San Diego, CA, USA, 1996.

14. Burns, R.G.; DeForest, J.L.; Marxsen, J.; Sinsabaugh, R.L.; Stromberger, M.E.; Wallenstein, M.D.; Weintraub, M.N.; Zoppini, A. Soil enzymes in a changing environment: current knowledge and future directions. Soil Biol. Biochem. 2013, 58, 216-234. [CrossRef]

15. Kirschbaum, M.U.F. The temperature dependence of organic-matter decomposition-Still a topic of debate. Soil Biol. Biochem. 2006, 38, 2510-2518. [CrossRef]

16. Friedlingstein, P.; Cox, P.; Betts, R.; Bopp, L.; Von Bloh, W.; Brovkin, V.; Cadule, P.; Doney, S.; Eby, M.; Fung, I. Climate-carbon cycle feedback analysis: Results from the C4MIP model intercomparison. J. Clim. 2006, 19, 3337-3353. [CrossRef]

17. Davidson, E.A.; Janssens, I.A. Temperature sensitivity of soil carbon decomposition and feedbacks to climate change. Nature 2006, 440, 165-173. [CrossRef] [PubMed]

18. Rustad, L.E.; Campbell, J.L.; Marion, G.M.; Norby, R.J.; Mitchell, M.J.; Hartley, A.E.; Cornelissen, J.; Gurevitch, J.; GCTE-NEWS. A meta-analysis of the response of soil respiration, net nitrogen mineralization, and aboveground plant growth to experimental ecosystem warming. Oecologia 2001, 126, 543-562. [CrossRef] [PubMed]

19. Wu, Z.; Dijkstra, P.; Koch, G.W.; Penuelas, J.; Hingate, B.A. Responses of terrestrial ecosystems to temperature and precipitation change: A meta-analysis of experimental manipulation. Glob. Chang. Biol. 2011, 17, 927-942. [CrossRef]

20. Stone, M.M.; Weiss, M.S.; Goodale, C.L.; Adams, M.B.; Fernandez, I.J.; German, D.P.; Allison, S.D. Temperature sensitivity of soil enzyme kinetics under $\mathrm{N}$-fertilization in two temperate forests. Glob. Chang. Biol. 2012, 18, 1173-1184. [CrossRef]

21. Davidson, E.A.; Janssens, I.A.; Luo, Y. On the variability of respiration in terrestrial ecosystems: Moving beyond Q10. Glob. Chang. Biol. 2006, 12, 154-164. [CrossRef]

22. Fierer, N.; Colman, B.P.; Schimel, J.P.; Jackson, R.B. Predicting the temperature dependence of microbial respiration in soil: A continental-scale analysis. Glob. Biogeochem. Cycles 2006, 20, GB3026. [CrossRef]

23. Paz-Ferreiro, J.; Trasar-Cepeda, C.; Leirós, M.D.C.; Seoane, S.; Gil-Sotres, F. Intra-annual variation in biochemical properties and the biochemical equilibrium of different grassland soils under contrasting management and climate. Biol. Fertil. Soils 2011, 47, 633-645. [CrossRef] 
24. Siddiqui, K.S.; Cavicchioli, R. Cold-adapted enzymes. Annu. Rev. Biochem. 2006, 75, 403-433. [CrossRef] [PubMed]

25. Miralles, I.; Ortega, R.; Sánchez-Marañón, M.; Leirós, M.C.; Trasar-Cepeda, C.; Gil-Sotres, F. Biochemical properties of range and forest soils in Mediterranean mountain environments. Biol. Fertil. Soils 2007, 43, 721-729. [CrossRef]

26. Cioci, C.; Corti, G.; Agnelli, A.; Cocco, S. Role of the altitude on the organic matter preservation in soils under a secondary prairie on the Majella massif (Italy). Agrochimica 2008, 52, 313-324.

27. Margesin, R.; Minerbi, S.; Schinner, F. Long-term monitoring of soil microbiological activities in two forest sites in South Tyrol in the Italian Alps. Microbes Environ. 2014, 29, 277-285. [CrossRef] [PubMed]

28. Xu, Z.; Yu, G.; Zhang, X.; Ge, J.; He, N.; Wang, Q.; Wang, D. The variations in soil microbial communities, enzyme activities and their relationships with soil organic matter decomposition along the northern slope of Changbai Mountain. Appl. Soil Ecol. 2015, 86, 19-29. [CrossRef]

29. Vittori Antisari, L.; Falsone, G.; Carbone, S.; Marinari, S.; Vianello, G. Douglas-fir reforestation in North Apennine (Italy): Performance on soil carbon sequestration, nutrients stock and microbial activity. Appl. Soil Ecol. 2015, 86, 82-90. [CrossRef]

30. Lucas, R.W.; Casper, B.B.; Jackson, J.K.; Balser, T.C. Soil microbial communities and extracellular enzyme activity in the New Jersey Pinelands. Soil Biol. Biochem. 2007, 39, 2508-2519. [CrossRef]

31. Centro Appenninico "C. Jucci". Temperature Massime, Minime, Medie Giornaliere, Escursioni Termiche, Precipitazioni Giornaliere e Giorni di Pioggia del Poliennio 1956-2014; Stazione meteorologica di Terminillo; Università degli Studi di Perugia: Perugia, Italy, 2015.

32. Spina, R.; Stortini, S.; Fusari, R.; Scuterini, C.; Di Marino, M. Caratterizzazione Climatologica delle Marche: Campo Medio della Temperatura per il Periodo 1950-2000; Centro di Ecologia e Climatologia, Osservatorio Geofisico Sperimentale: Macerata, Italy, 2006.

33. Amici, M.; Spina, R. Campo Medio della Precipitazione Annuale e Stagionale sulle Marche per il Periodo 1950-2000; Centro di Ecologia e Climatologia, Osservatorio Geofisico Sperimentale: Macerata, Italy, 2002.

34. Pasquale, V.; Verdoya, M.; Chiozzi, P.; Bodri, L.; Bellani, S. Temperature signal in the underground for climate history reconstruction in Italy. Glob. Planet. Chang. 2005, 47, 36-50. [CrossRef]

35. Desiato, F.; Fioravanti, G.; Fraschetti, P.; Perconti, W.; Piervitali, E. Il Clima Futuro in Italia: Analisi delle Proiezioni dei Modelli Regionali; Stato dell 'Ambiente 58; Istituto Superiore per la Protezione e la Ricerca Ambientale (ISPRA): Roma, Italy, 2015.

36. Schoeneberger, P.J.; Wysocki, D.A.; Benham, E.C.; Soil Survey Staff. Field Book for Describing and Sampling Soils; Version 3.0.; Natural Resources Conservation Service, National Soil Survey Center: Lincoln, NE, USA, 2012.

37. Soil Survey Staff. Keys to Soil Taxonomy, 12th ed.; USDA-Natural Resources Conservation Service: Washington, DC, USA, 2014.

38. Nelson, D.W.; Sommers, L.E. Total carbon, organic carbon, and organic matter. In Methods of Soil Analysis, Part 3. Chemical Methods; Sparks, D.L., Ed.; Soil Science Society of America Inc.: Madison, WI, USA, 1996.

39. Agnelli, A.; Bol, R.; Trumbore, S.E.; Dixon, L.; Cocco, S.; Corti, G. Carbon and nitrogen in soil and vine roots in harrowed and grass-covered vineyards. Agric. Ecosyst. Environ. 2014, 193, 70-82. [CrossRef]

40. Olsen, S.R.; Cole, C.V.; Watanabe, F.S.; Dean, L.A. Estimation of available phosphorus in soils by extraction with sodium bicarbonate. In USDA Circular; U.S. Government Printing Office: Washington, DC, USA, 1954; p. 19.

41. Vance, E.D.; Brookes, P.C.; Jenkinson, D.S. An extraction method for measuring microbial biomass C. Soil Biol. Biochem. 1987, 19, 703-707. [CrossRef]

42. Fornasier, F.; Margon, A. Bovine serum albumin and Triton X-100 greatly increase phosphomonoesterases and arylsulphatase extraction yield from soil. Soil Biol. Biochem. 2007, 39, 2682-2684. [CrossRef]

43. Cowie, A.L.; Lonergan, V.E.; Fazle Rabbi, S.M.; Fornasier, F.; Macdonald, C.; Harden, S.; Kawasaki, A.; Singh, B.K. Impact of carbon farming practices on soil carbon in northern New South Wales. Soil Res. 2013, 51, 707-718. [CrossRef]

44. Box, G.E.P.; Cox, D.R. Analysis of transformations. J. R. Stat. Soc. B (Stat. Methodol.) 1964, 26, $211-252$.

45. R Development Core Team. R: A Language and Environment for Statistical Computing; R Foundation for Statistical Computing: Vienna, Austria, 2008. Available online: http//www.cran.r-project.org (accessed on 16 May 2016). 
46. Riebe, C.S.; Kirchner, J.W.; Finkel, R.C. Sharp decrease in long-term chemical weathering rates along an altitudinal transect. Earth Planet. Sci. Lett. 2004, 218, 421-434. [CrossRef]

47. De Feudis, M.; Cardelli, V.; Massaccesi, L.; Bol, R.; Willbold, S.; Cocco, S.; Corti, G.; Agnelli, A. Effect of beech (Fagus sylvatica L.) rhizosphere on phosphorous availability in soils at different altitudes (central Italy). Geoderma 2016, 276, 53-63. [CrossRef]

48. Follett, R.F.; Stewart, C.E.; Pruessner, E.G.; Kimble, J.M. Effects of climate change on soil carbon and nitrogen storage in the US Great Plains. J. Soil Water Conserv. 2012, 67, 331-342. [CrossRef]

49. Zianis, D.; Mencuccini, M. Aboveground net primary productivity of beech (Fagus moesiaca) forest: A case study of Naousa forest, northern Greece. Tree Physiol. 2005, 25, 713-722. [CrossRef] [PubMed]

50. Pietikäinen, J.; Pettersson, M.; Bååth, E. Comparison of temperature effects on soil respiration and bacterial and fungal growth rates. FEMS Microbiol. Ecol. 2005, 52, 49-58. [CrossRef] [PubMed]

51. Xu, M.; Li, X.; Cai, X.; Li, X.; Christie, P.; Zhang, J. Soil microbial community structure and activity along a montane elevational gradient on the Tibetan Plateau. Eur. J. Soil Biol. 2014, 64, 6-14. [CrossRef]

52. Creamer, C.A.; De Menezes, A.B.; Krull, E.S.; Sanderman, J.; Newton-Walters, R.; Farrell, M. Microbial community structure mediates response of soil $\mathrm{C}$ decomposition to litter addition and warming. Soil Biol. Biochem. 2015, 80, 175-188. [CrossRef]

53. Agnelli, A.; Celi, L.; Degl 'Innocenti, A.; Corti, G.; Ugolini, F.C. The changes with depth of humic and fulvic acids extracted from fine earth and rock fragments of a forest soil. Soil Sci. 2002, 167, 524-538. [CrossRef]

54. Koch, O.; Tscherko, D.; Kandeler, E. Temperature sensitivity of microbial respiration, nitrogen mineralization, and potential soil enzyme activities in organic alpine soils. Glob. Biogeochem. Cycles 2007, 21, GB4017. [CrossRef]

55. Allison, S.D.; Wallenstein, M.D.; Bradford, M.A. Soil-carbon response to warming dependent on microbial physiology. Nat. Geosci. 2010, 3, 336-340. [CrossRef]

56. Wallenstein, M.; Allison, S.; Ernakovich, J.; Steinweg, J.M.; Sinsabaugh, R. Controls on the temperature sensitivity of soil enzymes: A key driver of in situ enzyme activity rates. In Soil Enzymology, Soil Biology; Shukla, G., Varma, A., Eds.; Springer: Berlin, Germany, 2011; pp. 245-258.

57. Lemanowicz, J.; Krzyzaniak, M. Vertical distribution of phosphorus concentrations, phosphatase activity and further soil chemical properties in salt-affected Mollic Gleysols in Poland. Environ. Earth Sci. 2015, 74, 2719-2728. [CrossRef]

58. Stutter, M.I.; Shand, C.A.; George, T.S.; Blackwell, M.S.A.; Dixon, L.; Bol, R.; MacKay, R.L.; Richardson, A.E.; Condron, L.M.; Haygarth, P.M. Land use and soil factors affecting accumulation of phosphorus species in temperate soils. Geoderma 2015, 257-258, 29-39. [CrossRef]

59. Nannipieri, P.; Giagnoni, L.; Landi, L.; Renella, G. Role of phosphatase enzymes in soil. In Phosphorus in Action; Bunemann, E.K., Obreson, A., Frossard, E., Eds.; Springer: Berlin, Germany, 2011; pp. 215-243.

60. Rejsek, K.; Vranova, V.; Pavelka, M.; Formanek, P. Acid phosphomonoesterase (E.C. 3.1.3.2) location in soil. J. Plant Nutr. Soil Sci. 2012, 175, 196-211. [CrossRef]

61. Brzostek, E.R.; Greco, A.; Drake, J.E.; Finzi, A.C. Root carbon inputs to the rhizosphere stimulate extracellular enzyme activity and increase nitrogen availability in temperate forest soils. Biogeochemistry 2013, 115, 65-76. [CrossRef]

62. Gunina, A.; Kuzyakov, Y. Sugars in soil and sweets for microorganisms: Review of origin, content, composition and fate. Soil Biol. Biochem. 2015, 90, 87-100. [CrossRef]

63. De Feudis, M.; Cardelli, V.; Massaccesi, L.; Hofmann, D.; Berns, A.E.; Bol, R.; Cocco, S.; Corti, G.; Agnelli, A. Altitude affects the quality of the water-extractable organic matter (WEOM) from rhizosphere and bulk soil in European beech forests. Geoderma 2017, 302, 6-13. [CrossRef]

(C) 2017 by the authors. Licensee MDPI, Basel, Switzerland. This article is an open access article distributed under the terms and conditions of the Creative Commons Attribution (CC BY) license (http:/ / creativecommons.org/licenses/by/4.0/). 